\title{
Pharmaceutical Application of Carbon Nanotubes Synthesized by Flame Fragments Deposition Method
}

\section{Falah H Hussein ${ }^{\star}$, Ban S Hasan, Massar B Mageed, Zeyad H Nafaee and Ghassan J Mohammed}

Department of Pharmaceuticals, College of Pharmacy, University of Babylon, P.O. Box 51002, Hilla, Iraq

"Corresponding author: Falah H Hussein, Department of Physical Chemistry, College of Pharmacy, University of Babylon, P.O. Box 51002, Hilla, Iraq, Tel: 009647804009236; E-mail: abohasan_hilla@yahoo.com

Received date: November 14, 2017; Accepted date: November 15, 2017; Published date: November 20, 2017

Copyright: ( 2017 Hussein FH, et al. This is an open-access article distributed under the terms of the Creative Commons Attribution License, which permits unrestricted use, distribution, and reproduction in any medium, provided the original author and source are credited.

\section{Editorial}

One of the most important applications of Carbon Nanotubes (CNTs) is their using in pharmacy as an excellent vehicle for drug delivery. Different techniques are used to synthesize CNTs. CNTs are used in medicine as a carries for drugs such as antibacterial to improve the penetrating capacity of drugs and reduce toxicity of using anticancer drug directly without carrier [1].

In our research laboratory CNTs were synthesized by using different carbon sources including date palm seeds [2], alcohols [3,4] and natural gas $[5,6]$. Synthesizing of CNTs from natural gas by Flame Fragments Deposition (FFD) may be considered as a clean technique and more suitable to use its yield in medical and pharmaceutical applications due to the absence of using any type of catalysts in this technique. Synthesized CNTs showed a high capacity for adsorption [7].

Sulfamethoxazole (SMX) is an antibiotic, used to treat a variety of bacterial infections. Adsorption is done by using SMX solutions with two concentrations $50 \mathrm{ppm}$ and $100 \mathrm{ppm} .25 \mathrm{ml}$ of SMX solutions of different concentrations were respectively stirred with $0.02 \mathrm{~g}$ MWNTs for 2 hours at $25^{\circ} \mathrm{C}$. After the adsorption experiment, the samples were filtrated by filter paper, then their clear solutions obtained were measured by spectrophotometry at $271 \mathrm{~nm}$ [8] for determination of sample concentrations.
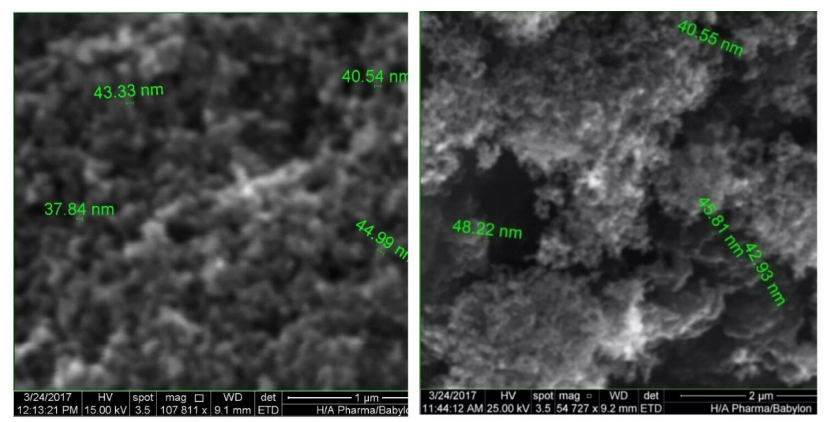

Figure 1: SEM images of synthesized carbon nanotubes from natural gas by flame fragments deposition.

SEM was used to determine the morphology of CNTs and to obtain information about the dimensions of nanotubes. FT-IR spectroscopy was used to obtain information about the location of functionalized groups of CNTs. The efficiency of CNTs in drug delivery was measured by adsorption of SMX on CNTs. Figure 1 shows the SEM images of synthesized CNTs from natural gas by using FFD method. These images show obtain high density of MWCNTs as agglomerates and also obtain amorphous carbon, and the elements are not found in this sample because the process of synthesis is without catalyst.

FT-IR spectroscopy of CNTs provided information of functionalized groups as shown in Figure 2. There were many peaks in rang 1713-989 $\mathrm{cm}^{-1}$. These bands of spectrum are related to a carbonyl group, amine group and olefin groups as well as bands between 1412 and $1000 \mathrm{~cm}^{-1}$ which are finger prints. This mean, the synthesized CNTs had no carboxyl and amine groups.

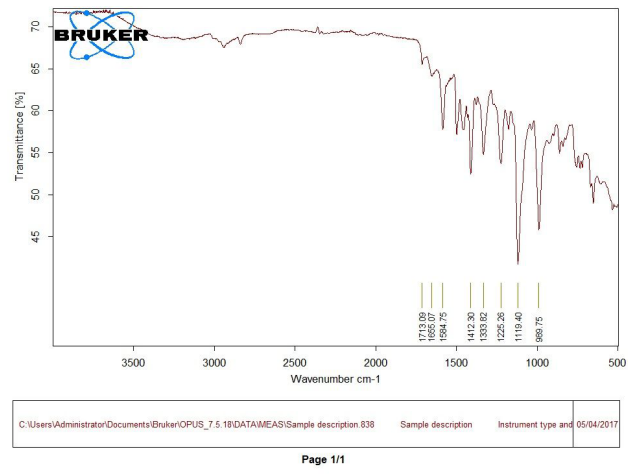

Figure 2: FT-IR spectroscopy of synthesized CNTs.

The adsorption efficiency of SMX on CNTs was compared for two concentrations of SMX as shown in Table 1. The higher adsorption efficiency was obtained when the concentration of SMX was high, along with increase of SMX concentration. The adsorption efficiency increased as well as, the loading quantity increased from $9.9875 \mathrm{mg} / \mathrm{g}$ to $55.357 \mathrm{mg} / \mathrm{g}$ when the concentration of SMX increases from 50 to $100 \mathrm{ppm}$. The adsorption efficiency commonly based on the Van der Waals interaction, $\pi-\pi$ staking interaction, electrostatic adsorption and simple hydrophobic interaction in their structure between CNTs and SMX. Generally, the drug loading efficiency of CNTs can be increased when CNTs are functionalized because of supply more adsorption and binding sites for SMX $[9,10]$.

\begin{tabular}{|l|l|l|l|l|}
\hline${ }^{*} \mathbf{Q}(\mathbf{m g} / \mathbf{g})$ & ${ }^{*}$ Au & ${ }^{*}$ As & ${ }^{*}$ Cu (ppm) & ${ }^{*}$ Cs (ppm) \\
\hline 9.9875 & 2.298 & 2.735 & 42.01 & 50 \\
\hline 55.357 & 2.212 & 3.97 & 55.717 & 100 \\
\hline
\end{tabular}

Table 1: The adsorption of SMX on carbon nanotubes. 
Citation: Hussein FH, Hasan BS, Mageed MB, Nafaee ZH, Mohammed GJ (2017) Pharmaceutical Application of Carbon Nanotubes Synthesized by Flame Fragments Deposition Method. J Environ Anal Chem 4: e115. doi:10.4172/2380-2391.1000e115

Page 2 of 2

${ }^{*} \mathrm{Cs}$ and $\mathrm{Cu}$ are the concentration of drug before and after adsorption, As and $\mathrm{Au}$ are the absorbance of drug before and after adsorption, $\mathrm{Q}$ is the amount of drug that adsorbed on the surface of CNTs.

\section{References}

1. He H, Pham-Huy LA, Dramou P, Xiao D, Zuo P, et al. (2013) Carbon Nanotubes: Applications in Pharmacy and Medicine. Hindawi Publishing Corporation, BioMed Research International 2013: 12.

2. Abdalrazak FH, Hussein FH (2014) Synthesis of carbon nanotubes from Iraqi date palm seeds. Patent C.O.S.Q.C, IRAQ, 4341, International classification B82Y30/00, C01B31/022, C01B31/0453.

3. Muhammed GJ, Abdulrazzak FH, Hussein FH (2015) Synthesis of MultiWalled Carbon Nanotube by using Ethanol as a Carbon Source. Chem Sci J 6: e106.

4. Muhammed GJ, Hussein F (2015) Synthesis of Carbon Nanotubes Using Aliphatic Alcohols as a Carbon Source. Chem Sci J 6: e110.
5. Hussein FH, Abdulrazzak FH, Alkaim AF (2017) Patent C.O.S.Q.C, IRAQ, 4975. International classification C01B2202/06, Y10S977/843.

6. Jassm AM, Hussein FH, Abdalrazak FH, Alkaim AF, Joda BA (2017) Synthesis and Characterization of Carbon Nanotubes by Modified Flame Fragments Deposition Method. Asian J Chem 29: 2804-2808.

7. Kamil AM, Abdalrazak FH, Halbus AF, Hussein FH (2014) Adsorption of Bismarck Brown R Dye Onto Multiwall Carbon Nanotubes. J Environ Anal Chem 1:104.

8. Jiang LI, Liu T, He H, Pham-Huy LA, Li L, et al. (2012) Adsorption Behavior of Pazufloxacin Mesilate on Amino-Functionalized Carbon Nanotubes. J Nanosci Nanotechnol 12: 7271-7279.

9. Goran V, Aleksandar M, Maja O, Velimir R, Miodrag C, et al. (2009) Synthesis, characterization and cytotoxicity of surface aminofunctionalized water-dispersible multi-walled carbon nanotubes. Appl Surf Sci 255: 8067-8075.

10. Hameed BH, Tan IAW, Ahmad AL (2008) Adsorption isotherm, kinetic modeling and mechanism of 2,4,6-trichlorophenol on coconut husk-based activated carbon. Chem Engineering J 144: 235-244. 